\title{
Correction to: Lignocellulose as an insoluble fiber source in poultry nutrition: a review
}

Ilen Röhe* and Jürgen Zentek

\section{Correction to: J Anim Sci Biotechnol 12, 82 (2021) \\ https://doi.org/10.1186/s40104-021-00594-y}

Following publication of the original article [1], the Additional table 1 was noticed to be incorrectly formatted. The correct Additional table 1 is included in this Correction below.

The original paper has been updated.

\section{Supplementary Information}

The online version contains supplementary material available at https://doi. org/10.1186/s40104-021-00623-w.

Additional file 1: Table 1. Overview on LC products used in the different studies.

Published online: 19 August 2021

\section{Reference}

1. Röhe I, Zentek J. Lignocellulose as an insoluble fiber source in poultry nutrition: a review. J Anim Sci Biotechnol. 2021;12:82 https://doi.org/10.11 86/s40104-021-00594-y.

The original article can be found online at https://doi.org/10.1186/s40104021-00594-y.

* Correspondence: ilen.roehe@fu-berlin.de

Department of Veterinary Medicine, Institute of Animal Nutrition, Freie

Universität Berlin, 14195 Berlin, Germany

C C The Author(s). 2021 Open Access This article is licensed under a Creative Commons Attribution 4.0 International License, which permits use, sharing, adaptation, distribution and reproduction in any medium or format, as long as you give appropriate credit to the original author(s) and the source, provide a link to the Creative Commons licence, and indicate if changes were made. The images or other third party material in this article are included in the article's Creative Commons licence, unless indicated otherwise in a credit line to the material. If material is not included in the article's Creative Commons licence and your intended use is not permitted by statutory regulation or exceeds the permitted use, you will need to obtain permission directly from the copyright holder. To view a copy of this licence, visit http://creativecommons.org/licenses/by/4.0/. The Creative Commons Public Domain Dedication waiver (http://creativecommons.org/publicdomain/zero/1.0/) applies to the data made available in this article, unless otherwise stated in a credit line to the data. 